\title{
Proteolytic cleavage of stingray phospholipase A2: Isolation and biochemical characterization of an active $\mathrm{N}$-terminal form
}

\author{
Abir G Ben Bacha ${ }^{1 *}$ and Hafedh Mejdoub²
}

\begin{abstract}
Background: Mammalian GIB-PLA2 are well characterized. In contrast, much less is known about aquatic ones. The aquatic world contains a wide variety of living species and, hence represents a great potential for discovering new lipolytic enzymes. The aim of this study was to check some biochemical and structural properties of a marine stingray phospholipase A2 (SPLA2).

Results: The effect of some proteolytic enzymes on SPLA2 was checked. Chymotrypsin and trypsin were able to hydrolyze SPLA2 in different ways. In both cases, only N-terminal fragments were accumulated during the hydrolysis, whereas no C-terminal fragment was obtained in either case. Tryptic and chymotryptic attack generated $13 \mathrm{kDa}$ and 12 $\mathrm{kDa}$ forms of SPLA2, respectively. Interestingly, the SPLA2 $13 \mathrm{kDa}$ form was inactive, whereas the SPLA2 $12 \mathrm{kDa}$ form conserved almost its full phospholipase activity. In the absence of bile slats both native and 12kDa SPLA2 failed to catalyse the hydrolysis of PC emulsion. When bile salts were pre-incubated with the substrate, the native kinetic protein remained linear for more than $25 \mathrm{~min}$, whereas the $12 \mathrm{kDa}$ form activity was found to decrease rapidly. Furthermore, The SPLA2 activity was dependent on $\mathrm{Ca}^{2+}$; other cations $\left(\mathrm{Mg}^{2+}, \mathrm{Mn}^{2+}, \mathrm{Cd}^{2+}\right.$ and $\left.\mathrm{Zn}^{2+}\right)$ reduced the enzymatic activity notably, suggesting that the arrangement of the catalytic site presents an exclusive structure for $\mathrm{Ca}^{2+}$.

Conclusions: Although marine and mammal pancreatic PLA2 share a high amino acid sequence homology, polyclonal antibodies directed against SPLA2 failed to recognize mammal PLA2 like the dromedary pancreatic one. Further investigations are needed to identify key residues involved in substrate recognition responsible for biochemical differences between the 2 classes of phospholipases.
\end{abstract}

\section{Introduction}

Phopholipases A2 (PLA2s) are esterases that catalyse the hydrolysis of acyl groups at the sn-2 position of glycerophospholipids (PL) and produce free fatty acids, such as arachidonic acid, and lyso-PL by an interfacial activation catalytic mechanism [1].

A large number of distinct PLA2s have been characterized and classified into the broad categories of intracellular and secreted forms of the enzyme. Intracellular (cytosolic) PLA2s participate in cellular eicosanoid metabolism and signal transduction. Numerous isoforms of secretory phospholipases (sPLA2s) have been identified and divided into several groups, based on their

\footnotetext{
* Correspondence: abirghanouchi@yahoo.fr

'Biochemistry Department, Science College, King Saud University, P.O box 22452, Zip code 11495, Riyadh, Saudi Arabia

Full list of author information is available at the end of the article
}

amino acid sequences, structures, catalytic mechanisms, tissue distributions and evolutionary relationships [1,2]. Ten human secreted PLA2s have been cloned: group (G) IB, GIIA, GIID, GIIE, GIIF, GIII, GV, GX, and GXIIA PLA2s and the GXII PLA2-like protein that is devoid of catalytic activity [3] and [4]. sPLA2s are low molecular weight enzymes $(14 \mathrm{kDa})$ and are abundant in various mammalian tissues and fluids. These enzymes are involved in various normal and pathological cell functions [1]. A Group IB enzyme was first found in mammalian pancreatic exudates, and therefore is known as pancreatic PLA2. The main physiologic function of GIB PLA2 is to digest dietary phospholipids. GIB PLA2 is synthesized in pancreatic acinar cells and secreted into the duodenal lumen as an enzymatically inactive PLA2 that is activated by cleavage of a 7-amino acid activation peptide by trypsin [5].

\section{Biomed Central}


The $\mathrm{PLA}_{2} \mathrm{~s}$ from mammalian pancreas and snake venoms have been used as diagnostic biochemical reagents. In fact snake venom $\mathrm{SPLA}_{2} \mathrm{~s}$ were employed to analyse the position of fatty acids in phospholipids from guina pig and pic cardiac membranes [6]. Moreover, porcine $\mathrm{PLA}_{2}$ (PPLA2) was used in the examination of the structural and functional changes of egg yolk low density lipoproteins (LDL) by modifying its phospholipids [7]. In addition, $\mathrm{PPLA}_{2}$ was used in industrial processes in the food industry to produce lyso PC which is an excellent emulsifier for food [8]. The biology and the biochemistry of mammalian and venom $\mathrm{PLA}_{2}$ are well documented. In contrast, few studies were reported on the enzymology and application of $\mathrm{PLA}_{2}$ from marine organisms [9]. Therefore, little information is available on marine gastropod mollusc's sPLA 2 [10-16]. To date, few studies exist on phospholipase from the digestive gland of marine organisms. Recently, we have purified stingray PLA2 (SPLA2) from the common stingray Dasyatis pastinaca and some of its catalytic properties were determined [17]. High similarity was found between the N-terminal amino acid residues of SPLA2 and those of other known pancreatic PLA2. In the presence of organic solvents, as well as in acidic and alkaline $\mathrm{pH}$ and at high temperature, SPLA2 stability makes it a good candidate for its application in food industry. It seems therefore of interest to check some other catalytic and structural properties of SPLA2 to gain more insights into their action mode on phospholipids. We have therefore performed the limited proteolysis experiments on SPLA2, using trypsin and chymotrypsin. Profiles regarding proteolysis and activity are reported.

\section{Material and methods}

\subsection{Proteins}

SPLA2 and DrPLA2 were purified as described by Ben Bacha et al., [17,18]. Protein concentration was determined as described by Bradford et al. [19] using BSA (E $=6.7$ ) as reference.

\subsection{Determination of phospholipase activity}

The stingray PLA2 activity was measured titrimetrically at $\mathrm{pH} 8.5$ and at $40^{\circ} \mathrm{C}$ with a $\mathrm{pH}$-stat, under the optimum conditions, using purified egg phosphatidylcholine (PC), phosphatidylserine (PS) or phosphatidylethanolamine (PE) emulsions as substrate in the presence of 4 $\mathrm{mM} \mathrm{NaTDC}$ and $8 \mathrm{mM} \mathrm{CaCl} 2$ [20]. One unit of phospholipase activity was defined as $1 \mu$ mole of fatty acid liberated under standard conditions.

\subsection{Limited proteolysis}

SPLA2 (1 mg) was dissolved in $1 \mathrm{ml}$ of $50 \mathrm{mM}$ Tris- $\mathrm{HCl}$ buffer, pH 8.5 without benzamidine. The PLA2 solution was digested at 4,30 and $37^{\circ} \mathrm{C}$ with the selected endopeptidase. The endopeptidase/PLA2 molar ratio varied from 0.01 to 0.1 . Samples $(50 \mu \mathrm{l})$ were withdrawn from the incubation mixture at various times to assess the residual activity and the electrophoretic profile. The reaction was stopped by addition of benzamidine $(4 \mathrm{mM}$ final concentration).

\subsection{Analytical methods}

Analytical polyacrylamide gel electrophoresis of proteins in the presence of sodium dodecyl sulfate (SDS-PAGE) was performed by the method of Laemmli [21]. Samples for sequencing or immunoblotting were electrotransferred onto polyvinylidene difluorid and a nitrocellulose membrane respectively [22]. Protein transfer was performed during $2 \mathrm{~h}$ at $4 \mathrm{~mA} / \mathrm{cm}^{2}$ at room temperature.

\subsection{Amino acid sequencing}

The N-terminal sequence was determined by automated Edman's degradation, using an Applied Biosystems Protein Sequencer Procise 492 equipped with 140 C HPLC system [23].

\subsection{Production of polyclonal antibodies}

Polyclonal antibodies directed against purified SPLA2 were produced on rabbits after subcutaneous and intramuscular injections every 3 weeks of $0.5 \mathrm{mg}$ of pure SPLA2. The first injection included complete Freund's adjuvant, while the last two injections contained incomplete adjuvant.

\subsection{Immunoblotting technique}

The reactivity of anti-SPLA2 serum with PLA2 (SPLA2 or DrPLA2) was checked using immunoblotting technique. After protein transfer, membranes were rinsed three times with PBS (phosphate buffer saline: $10 \mathrm{mM}$ phosphate $\mathrm{pH} 7.2,150 \mathrm{mM} \mathrm{NaCl}$ ), then saturated with $3 \%$ of milk powder in PBS (saturating buffer) for $1 \mathrm{~h}$ at room temperature. Thereafter, anti-SPLA2 serum diluted at 1:1000 with PBS containing 0.05\% Tween-20 (PBS/Tween-20) were incubated with the membranes for $1 \mathrm{~h}$ at room temperature. Afterwards, membranes were washed three times with PBS/Tween-20 then incubated for $1 \mathrm{~h}$ at room temperature with a 1:2000 dilution of alkaline phosphatase-conjugated anti-rabbit immunoglobulin (Sigma). After washing, as mentioned above, membranes were incubated with a phosphatase substrate solution containing $0.3 \mathrm{mg} / \mathrm{ml}$ of nitroblue tetrazolium chloride (Sigma), $0.2 \mathrm{mg} / \mathrm{ml}$ of 5 -bromo-4chloro-3 indolyl-phosphate (Sigma) and $0.2 \mathrm{mg} / \mathrm{ml}$ of $\mathrm{MgCl}_{2}$ to reveal the specific immunoreactivity.

\subsection{Enzyme linked immunosorbent assay (ELISA) analysis}

The immunoreactivity of anti-SPLA2 polyclonal antibodies with phospholipases (SPLA2 or DrPLA2) was 
checked, using the ELISA technique. Purified phospholipases (SPLA2 or DrPLA2) were diluted using coating buffer (PBS) to obtain a final concentration of $1 \mu \mathrm{g} / \mathrm{ml}$. Aliquots $(100 \mu \mathrm{l})$ were coated onto polyvinyl chloride microtiter wells and incubated overnight at $4^{\circ} \mathrm{C}$. The wells were then saturated by adding $100 \mu \mathrm{l}$ of saturating buffer (3\% of powder milk in PBS) for $2 \mathrm{~h}$ at $37^{\circ} \mathrm{C}$. Thereafter, $100 \mu \mathrm{l}$ of serum, diluted at 1:500 with saturating buffer, were added to each well and the plates were incubated for $1 \mathrm{~h}$ at $37^{\circ} \mathrm{C}$. Afterwards, $100 \mu \mathrm{l}$ of peroxidase-conjugated anti-rabbit immunoglobulin (Sigma) diluted at 1:2000 with saturating buffer were added to each well and the plates were kept at $37^{\circ} \mathrm{C}$ for an additional hour. Then, $100 \mu \mathrm{l}$ of freshly prepared peroxidase substrate solution (an o-phenylenediamine tablet (Sigma) was solubilized in $50 \mathrm{mM}$ sodium phosphate/ citrate, $\mathrm{pH} 5$ containing $0.4 \%$ of fresh hydrogen peroxide) were added to each well. The plates were incubated in the dark for $30 \mathrm{~min}$ at room temperature. The enzymatic reaction was then stopped by adding $50 \mu \mathrm{l}$ of 0.5 $\mathrm{M} \mathrm{H}_{2} \mathrm{SO}_{4}$. The absorbance was read at $490 \mathrm{~nm}$ in a micro-ELISA reader (Dynatech).

\section{Results and discussion}

\subsection{Level of expression of SPLA2 activity}

In order to compare the level of stingray PLA2 activity with other species, the rate of hydrolysis of PC emulsion by dromedary, bovine, chicken, and turkey pancreases were measured under the same conditions. Results reported in Table 1 show that the pancreases tested secreted various levels of PLA2 activity. The highest level was observed with turkey $(200 \mathrm{U} / \mathrm{g})$. Sheep presented only $10 \mathrm{U} / \mathrm{g}$ in its pancreas.

Table 1 Pancreatic PLA2 levels in some animals

\begin{tabular}{ccc}
\hline Species & $\begin{array}{c}\text { PLA2 activity } \\
\text { (U/g fresh pancreas) }\end{array}$ & References \\
\hline Stingray & $55 \pm 5$ & Present study \\
\hline Dromedary & $20 \pm 3.5$ & {$[18]$} \\
\hline Turkey & $200 \pm 20$ & {$[18]$} \\
\hline Bovine & $110 \pm 17$ & {$[18]$} \\
\hline Chicken & $70 \pm 25$ & {$[18]$} \\
\hline Sheep & $10 \pm 5$ & {$[18]$} \\
\hline
\end{tabular}

The determination of the phospholipase content of pancreases from all species was performed in a homogenate prepared in a Waring Blendor $(2 \times$ 30 s) with $10 \mathrm{ml}$, per gram of fresh tissue, of $10 \mathrm{mM}$ Tris-HCl, $150 \mathrm{mM} \mathrm{NaCl}$, and $\mathrm{pH} 8.5$ at room temperature. After centrifugation at $12.000 \mathrm{rpm}$ during 20 min, the amount of enzyme was estimated on an aliquot of the supernatant using PC emulsion as substrate in the presence of $4 \mathrm{mM}$ NaTDC and $8 \mathrm{mM}$ $\mathrm{CaCl}$ 2. The phospholipase activity was measured titrimetrically at $\mathrm{pH} 8.0$ and at $37^{\circ} \mathrm{C}$ using a pH-stat. One phospholipase unit corresponds to one $\mu$ mole of fatty acid released per min using PC emulsion as substrate in the presence of $4 \mathrm{mM} \mathrm{NaTDC}$ and $8 \mathrm{mM} \mathrm{CaCl} 2$. For each species, the activity represents the average \pm standard error mean of five assays obtained from three different pancreases.

\subsection{Annual distribution of the SPLA2 activity levels}

Dasyatis pastinaca used in this study were collected every month between January and December and the SPLA2 activity was observed monthly. As we can see from Figure 1, no significant difference in the PLA2 activity was observed in the monthly collected samples. A slight increase in phospholipase activity was measured during the summer (May to July). This increase can be related to the reproduction activity during this period and to the increase of the temperature of the sea water. Then, Ismen (2003) [24], indicated that this species presented a high reproduction activity from May to September. Moreover, Spawning occurred mainly from May to September, apparently triggered by the rising seawater temperature during summer.

\subsection{Effect of metal ions on SPLA2 activity}

The SPLA2 showed a strict dependence on calcium ions (8 $\mathrm{mM})$ for full activity using PC as substrate. The addition of $\mathrm{Mg}^{2+}, \mathrm{Mn}^{2+}, \mathrm{Cd}^{2+}$ and $\mathrm{Zn}^{2+}(10 \mathrm{mM})$ in the absence or presence of low $\mathrm{Ca}^{2+}$ concentration $(1 \mathrm{mM})$ significantly decreased the enzyme activity (Table 2). The obtained data showed that substitution of $\mathrm{Ca}^{2+}$ by other divalent ions $\left(\mathrm{Mg}^{2+}, \mathrm{Mn}^{2+}, \mathrm{Cd}^{2+}, \mathrm{Zn}^{2+}\right)$ were not able to keep the substrate bound to the enzyme, only $\mathrm{Ca}^{2+}$ supported the catalytic activity (Table 2). This can be explained by different coordination geometries assumed by the tetrahedral intermediate due to the presence of the $\mathrm{Ca}^{2+}$ ion which not only determines the electrophilic behavior of the catalytic site, but also stabilizes the otherwise flexible $\mathrm{Ca}^{2+}$-binding loop and appears to optimize the local protein conformation for substrate interactions $[25,26]$. Other metals fail to productively bind to the enzyme, competitively inhibit $\mathrm{Ca}^{2}$ ${ }^{+}$-mediated activity, or prove to be weakly active [27].

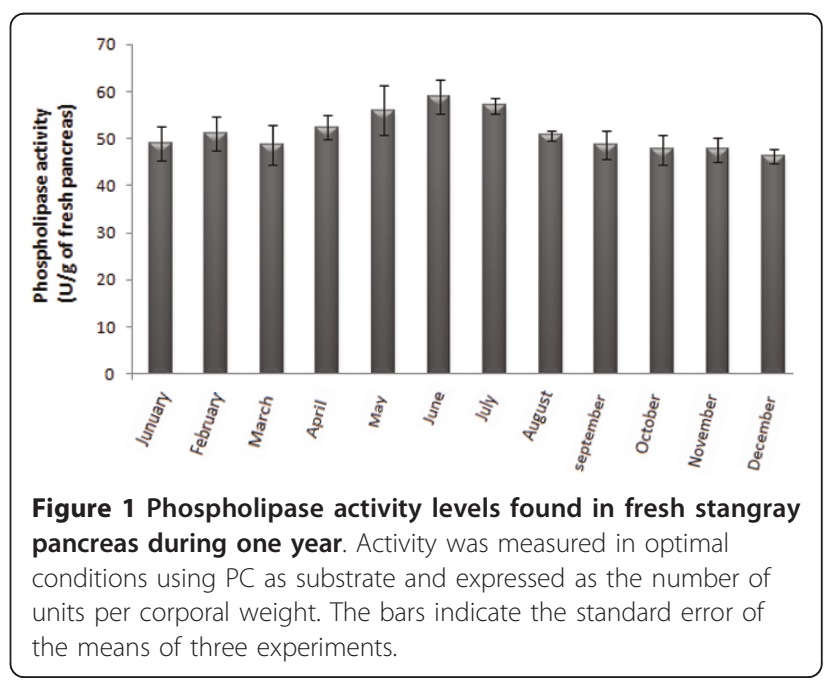


Table 2 Effects of different metal ions on the activity of stingray PLA2

\begin{tabular}{lcc}
\hline lons & \multicolumn{2}{c}{ PLA2 Activity (\%) } \\
\cline { 2 - 3 } & $\mathbf{0 ~} \mathbf{~ m ~ C a}$ & $\mathbf{1} \mathbf{~ m M ~ C a}^{2+}$ \\
\hline $\mathbf{M g}^{2+}$ & $3.5 \pm 1.1$ & $60 \pm 5.4$ \\
\hline $\mathbf{M n}^{2+}$ & $2 \pm 1$ & $57 \pm 2.2$ \\
\hline $\mathbf{Z n}^{2+}$ & $3 \pm 0.5$ & $15 \pm 2.4$ \\
\hline $\mathrm{Cd}^{2+}$ & $2 \pm 0.8$ & $12 \pm 1.8$
\end{tabular}

Influence of ions concentrations (10 mM each) on SPLA2 activity in the absence or presence of $1 \mathrm{mM} \mathrm{Ca}{ }^{2+}$ was studied using PC emulsion as substrate at $40^{\circ} \mathrm{C}$ and $\mathrm{pH} 8.5$. The control represents $100 \%$ of PLA2 activity at 8 $\mathrm{mM} \mathrm{Ca}^{2+}$ under the same condition. Values represent the mean of three replicates.

Interestingly $\mathrm{Mg}^{2+}$ and $\mathrm{Mn}^{2+}$ in presence of low $\mathrm{Ca}^{2+}$ concentrations support a significant catalytic activity.

\subsection{Immunochemical properties}

The supernatant of the stingray pancreas homogenate containing $200 \mu \mathrm{g}$ of total proteins was subjected to SDS-PAGE analyses followed by immunoblotting using anti-SPLA2 serum. Our results showed that anti- SPLA2 serum reacted with a single band $(14 \mathrm{kDa})$ corresponding to the SPLA2 present in the crude extract (Figure $2 \mathrm{~A}$, lane 1 ). No other protein bands were recognized by this serum. This result suggests a good specificity of this serum toward SPLA2. Anti-SPLA2 serum was used to carry out cross-reactivities between SPLA2 and DrPLA2 using the ELISA and the Western blotting techniques. SPLA2 was strongly recognized by anti- SPLA2 serum and no cross-immunoreactivity was detected with DrPLA2 (Figure 2A, lanes 1 and 2). For the ELISA technique used for the sake of better sensibility, microtitration plates were coated with a fixed amount of pure SPLA2 and incubated with an antiserum diluted 100 times. Only SPLA2 reacted strongly with its corresponding antiserum (Figure $2 \mathrm{~B}$ ). Figure $2 \mathrm{C}$ shows the effect of the anti-SPLA2 antibody on the activities of SPLA2 and DrPLA2. In this experiment, we used an identical PLA2 concentration. The inhibition pattern for marine PLA2 was different from that of mammal one. The antiSPLA2 antibody, which almost completely inhibited the SPLA2 activity at $0.1 \mathrm{mg} / \mathrm{ml}$, had no effect on the dromedary enzyme. These results might be explained by the fact that SPLA2 may not share common antigenic determinants with classical pancreatic PLA2. Although the 20 residues of SPLA2-NH2-terminal end showed significant homology with those of pancreatic PLA2, the absence of immunoreactivity between DrPLA2 and antiSPLA2 serum strengthens the idea that SPLA2 could be structurally different from mammalian pancreatic PLA2. This hypothesis needs further structural and biochemical investigations.

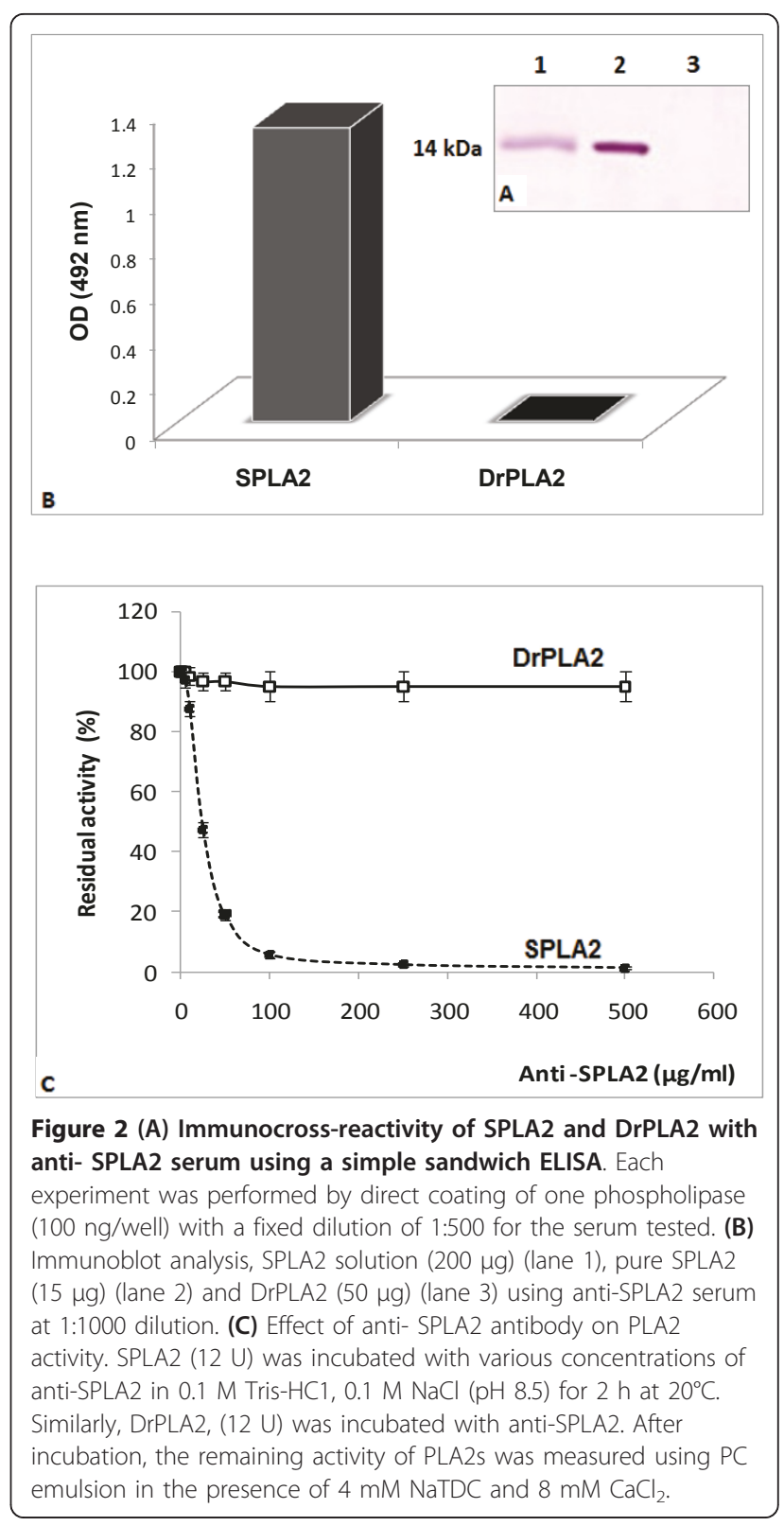

\subsection{Cleavage of SPLA2}

The SPLA2 incubation with trypsin at $30^{\circ} \mathrm{C}$ and using a protease/PLA2 molar ratio of 0.05 generated three major fragments: T1 (13 kDa), T2 $(8 \mathrm{kDa})$, T3 $(5 \mathrm{kDa})$ and $\mathrm{T} 4(4 \mathrm{kDa})$ with a decrease of PLA 2 activity by half within $4 \mathrm{~h}$ (Figure $3 \mathrm{~A}$ and $3 \mathrm{~B}$ ). These fragments were transferred on a PVDF membrane and their $\mathrm{N}$ terminal amino acid was sequenced. The results are given in table 3 together with the corresponding sequences from the PPLA2. The N-terminal sequencing showed that the larger $13 \mathrm{kDa}$ fragment (T1) corresponded to an N-terminal truncated form of SPLA2 starting at residue $\mathrm{C} 11$. This $\mathrm{N}$-terminal truncated 


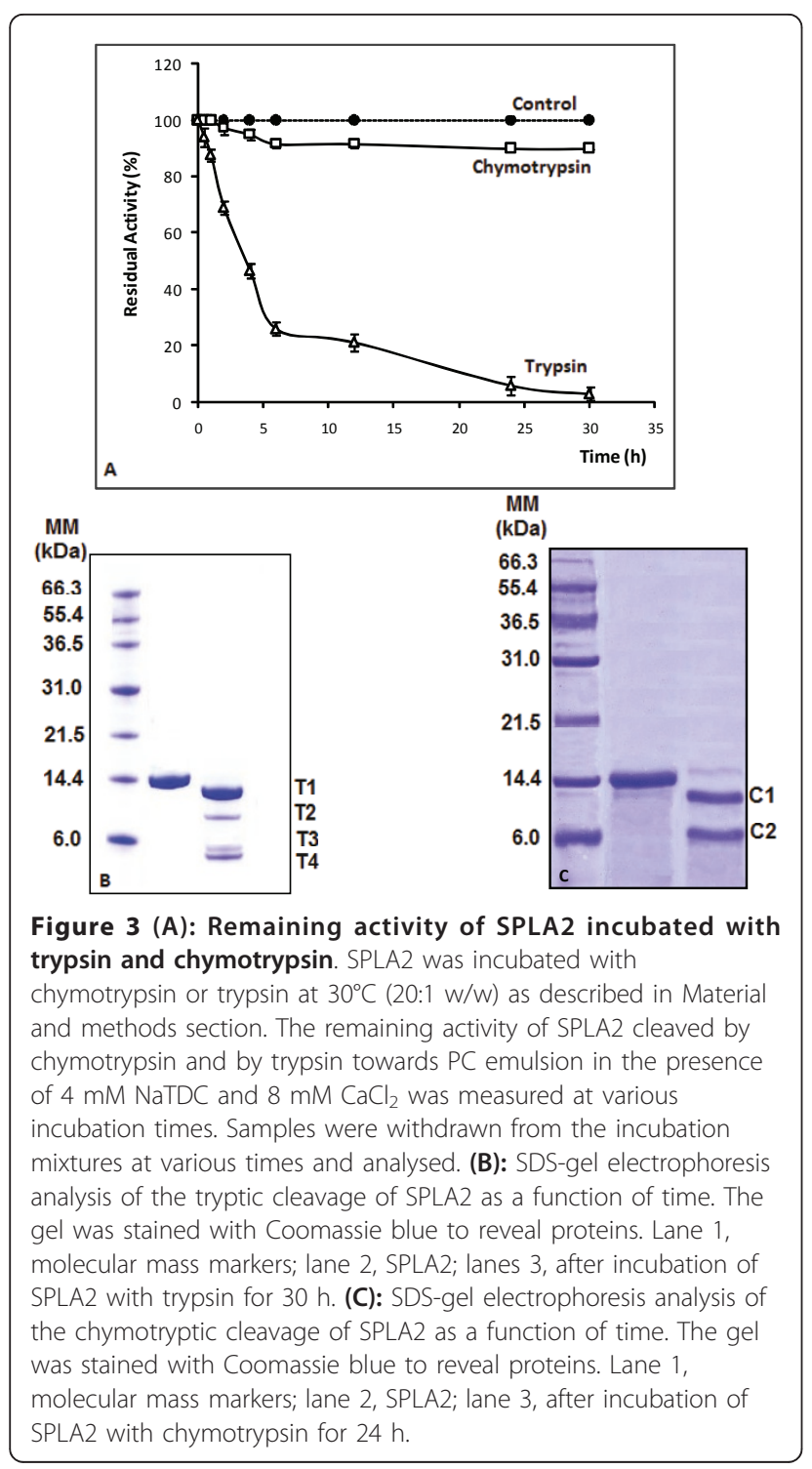

SPLA2 form (13 kDa) was thus generated from cleavage by trypsin of the K10-C11 bond of SPLA2. The T3 and T4 bands had the same $\mathrm{N}$-terminal sequences as the T1 peptide; whereas The T2 peptide started at residue C66. Based on its molecular mass $(7 \mathrm{kDa})$, this band would correspond to the SPLA2 $(14 \mathrm{kDa})$ lacking $\mathrm{N}$-terminal 65 amino acids. These results suggested that SPLA2 possessed basic residue at position 65 corresponding to $\mathrm{R}$ amino acid for PPLA2 and allowing the tryptic cleavage to occur.

Our results showed that the deletion of the N-terminal fragment of SPLA2 (residue A1 to K10) resulted in a loss of the enzyme activity and, thus, provided evidence that the $\mathrm{N}$-terminal fragment was a crucial structural domain necessary for the activity of the enzymes. These findings collaborate with previous findings
Table 3 Sequences comparison of protein fragments isolated after chymotryptic and tryptic proteolysis of SPLA2 with PPLA2

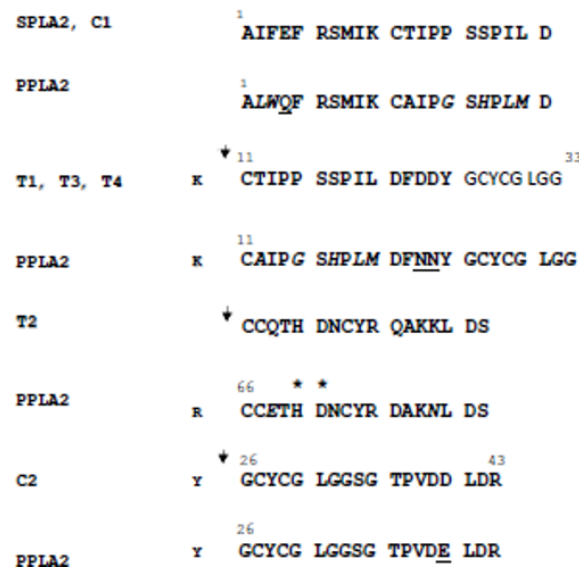

PPLA2

For comparison, bold, underlined, and italic symbols of residues indicate identical, homologous, and different amino acids, respectively. The $\mathrm{Ca}^{2+}$ loop (C27-G32) is bold shaded. Stars indicate the amino-acid residues of the catalytic triad. The arrows indicate the tryptic or chymotryptic cleavage site of SPLA2.

demonstrating that Helix 1 at the $\mathrm{N}$-terminal of human group 1B PLA2 (hG1B) play an important role in enzyme function. An engineered hG1B lacking the Nterminal helix 1 bound to membranes with weaker affinity exhibited $\sim 100$-fold lower enzymatic activity compared with that of the full-length hG1B. It is inferred that this helix 1 facilitates the membrane binding, thus enhances the enzymatic activity based on polarized infrared spectroscopic experiments [28]. Experiments using semi-synthetic hG1B demonstrated that helix 1 residues act as a regulatory domain and mediate interfacial activation [29].

Conversely, when incubated with chymotrypsin under the same conditions as described above, the protein band corresponding to the native SPLA2 disappeared within $24 \mathrm{~h}$; whereas 2 major bands $(\mathrm{C} 1$, and $\mathrm{C} 2)$ of different sizes, of about 12 , and $7 \mathrm{kDa}$ were accumulated (Figure 4B). The $\mathrm{N}$-terminal sequence of the $\mathrm{C} 1 \mathrm{frag}$ ment was the same as the native PLA2. This shows that this $12 \mathrm{kDa}$ fragment is thus issued from a C-terminal truncation of the SPLA-2. The sequencing of the $7 \mathrm{kDa}$ fragment showed that it was generated upon cleavage by chymotrypsin of the Y25-G26 bond of SPLA2. Interestingly, the chymotryptic cleavage was not accompanied by any loss of the PLA2 activity assayed on PC emulsion. Furthermore, no C-terminal fragment was detected after proteolysis. The $\mathrm{N}$-terminal $\mathrm{C} 1$ fragment alone seemed therefore to be active, despite the absence of the C-terminal fragment.

The 12-kDa form was further purified by filtration on Bio-sil SEC-125 HPLC gel filtration column $(300 \times 7.8$ $\mathrm{mm}$ ) equilibrated with phosphate $0.1 \mathrm{M}$ buffer $\mathrm{pH} 7.0$ 


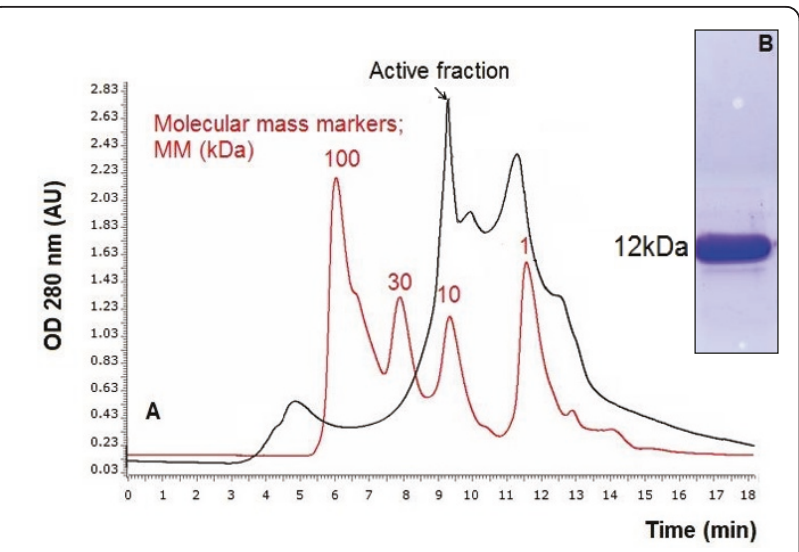

Figure 4 Filtration on HPLC column and SDS-PAGE (15\%) of fragments resulting from chymotryptic cleavage of SPLA2. (A) An aliquot of the incubation mixture $(0.1 \mathrm{mg}$ in $0.1 \mathrm{ml})$ was applied to a HPLC column Bio-sil SEC-125 (300 mm $\times 7.8 \mathrm{~mm}$ ) equilibrated in $0.1 \mathrm{M}$ phosphate buffer $\mathrm{pH} 6.8$ containing $0.15 \mathrm{M} \mathrm{NaCl}$, elution was performed at room temperature within 20 min with the same buffer at a flow rate of $1 \mathrm{ml} / \mathrm{min}$. Molecular mass markers were used to estimate the molecular masses of eluted proteins. The effluent was monitored at $280 \mathrm{~nm}$. AU: arbitrary units. (B) SDS-PAGE (15\%) of the active fraction eluted from HPLC filtration. The gel was stained with Comassie blue to reveal proteins.

containing $0.15 \mathrm{M} \mathrm{NaCl}$. Elution of proteins was performed with the same buffer at $30 \mathrm{ml} / \mathrm{h}$ and SPLA2 emerged $9 \mathrm{~min}$ after injection (Figure 4A). The fractions containing the PLA2 activity were pooled, and SDS/ PAGE analysis revealed only one band corresponding to 12 kDa SPLA2 (Figure 4B).

In order to get more new insights into the mode of protein/substrate interaction, more kinetic behaviour of $12-\mathrm{kDa}$ fragment was checked. The rate of hydrolysis of different concentrations of PC, PE and PS were measured under optimal conditions ( $4 \mathrm{mM} \mathrm{NaTDC}, 8 \mathrm{mM}, \mathrm{CaCl}_{2}$, and $\mathrm{pH} 8.5$ and $40^{\circ} \mathrm{C}$ ). The Lineweaver-Burk curves were plotted (data not shown). From these fits, the substrate affinity constants (KM) and the turnover of the enzymatic reaction (kcat) were obtained and shown with the deduced catalytic efficiency (kcat/KM) in Table 4. For further comparison, we reported in the same Table 4 the kinetic parameter values obtained with the native SPLA2, and DrPLA2 under the same conditions.
From these values, one can say that the two marine PLA2s, showing essentially the same activity toward all the tested substrates, hydrolyse the different phospholipids more efficiently than mammalian one since the ratio representing the catalytic efficiency $(\mathrm{Kcat} / \mathrm{Km})$ is about 1.5-2 times higher with native SPLA2 and $12 \mathrm{kDa}$ SPLA2 than with DrPLA2.

On the other hand, marine and mammalian PLA2 preferentially hydrolyse the phospholipids in the following order PE > PC > PS. Only one unique feature was noted from the activity of $12 \mathrm{kDa}$ SPLA2 toward various substrates. The $12 \mathrm{kDa}$ form activity was found to decrease rapidly, in the presence of bile salts and calcium (Figure 5). Under the same conditions, native SPLA2 and DrPLA2 were able to hydrolyze efficiently the different substrates without any denaturation and the kinetics remained linear for more than $25 \mathrm{~min}$ (Figure 5). Similar results were obtained when PE or PS were used as substrate (Data not shown).

Several studies have provided evidence that bile salts are tensioactive agents ensuring in their micellar form, the dispersion of the lipolytic products (of hydrolysis) $[30,31]$. Along the same line, De Haas et al. reported that micellar forms of the substrate were hydrolyzed at a much higher rate than substrates molecularly dispersed by PLA2 [32]. As previously reported SPLA2 and DrPLA2 failed to catalyze the hydrolysis of pure PC. To trigger the PLA2 activity on PC, NaTDC was added prior to the enzyme injection $[17,18]$. In its presence, the kinetics remained linear for more than 25 min (Figure 5). Similar result was obtained with $12 \mathrm{kDa}$ SPLA2 (data not shown), whereas, the pancreatic chicken PLA2 (ChPLA2) was found to hydrolyze efficiently PC in the absence of NaTDC and its maximum specific activity was found to be nearly independent of NATDC [33]. This difference between SPLA2, DrPLA2 and ChPLA2 might be explained by structural variation of exposed residues between the different phospholipases.

Previous work reported that the overall structural and functional perturbations caused by deleting nine C-terminus residues of bovine pancreatic PLA2 over expressed in Escherichia coli were modest, but the C-terminus deletion mutant displayed an interesting and significant property. It

Table 4 Apparent kinetic parameters of SPLA2, 12 kDa SPLA2 and DrPLA2

\begin{tabular}{|c|c|c|c|c|c|c|c|c|c|c|c|c|}
\hline & \multicolumn{3}{|c|}{$\mathrm{V}_{\max }(\mathrm{U} / \mathrm{mg})$} & \multicolumn{3}{|c|}{$\mathrm{K}_{\mathrm{m}}(\mathrm{mM})$} & \multicolumn{3}{|c|}{$\mathrm{K}_{\text {cat }}\left(\mathrm{s}^{-1}\right)$} & \multicolumn{3}{|c|}{$\mathrm{K}_{\mathrm{cat}} / \mathrm{K}_{\mathrm{m}}\left(\mathrm{mM}^{-1} \mathrm{~s}^{-1}\right)$} \\
\hline & PE & PC & PS & PE & PC & PS & PE & PC & PS & PE & PC & PS \\
\hline SPLA2 & $\begin{array}{c}2850 \pm \\
200\end{array}$ & $\begin{array}{c}750 \pm \\
50\end{array}$ & $\begin{array}{c}290 \pm \\
15\end{array}$ & $\begin{array}{c}13 \pm \\
0.7\end{array}$ & $\begin{array}{c}17.33 \pm \\
0.5\end{array}$ & $\begin{array}{c}20 \pm \\
1.3\end{array}$ & $669 \pm 5.2$ & $\begin{array}{c}187 \pm \\
2.65\end{array}$ & $68 \pm 2.7$ & $51.5 \pm 3.7$ & $\begin{array}{c}11.5 \pm \\
0.5\end{array}$ & $3.4 \pm 0.8$ \\
\hline $\begin{array}{l}12 \mathrm{kDa} \\
\text { SPLA2 }\end{array}$ & $\begin{array}{c}2730 \pm \\
150\end{array}$ & $\begin{array}{c}700 \pm \\
80\end{array}$ & $\begin{array}{c}300 \pm \\
17\end{array}$ & $\begin{array}{c}13.8 \pm \\
1\end{array}$ & $16.5 \pm 0.9$ & $\begin{array}{c}22 \pm \\
0.7\end{array}$ & $640.8 \pm 7$ & $\begin{array}{c}146.3 \pm \\
3.8\end{array}$ & $\begin{array}{c}70.42 \pm \\
3.3\end{array}$ & $47.4 \pm 2.2$ & $\begin{array}{c}9.96 \pm \\
0.3\end{array}$ & $3.2 \pm 0.3$ \\
\hline DrPLA2 & $\begin{array}{c}2300 \pm \\
120\end{array}$ & $\begin{array}{c}600 \pm \\
45\end{array}$ & $\begin{array}{c}190 \pm \\
12\end{array}$ & $\begin{array}{c}16 \pm \\
1.2\end{array}$ & $22 \pm 0.9$ & $\begin{array}{c}28 \pm \\
1.5\end{array}$ & $\begin{array}{c}539.9 \pm \\
10\end{array}$ & $140 \pm 2.7$ & $44.6 \pm 1.9$ & $\begin{array}{c}33.74 \pm \\
2.8\end{array}$ & $\begin{array}{c}6.36 \pm \\
0.7\end{array}$ & $\begin{array}{c}2.03 \pm \\
0.1\end{array}$ \\
\hline
\end{tabular}




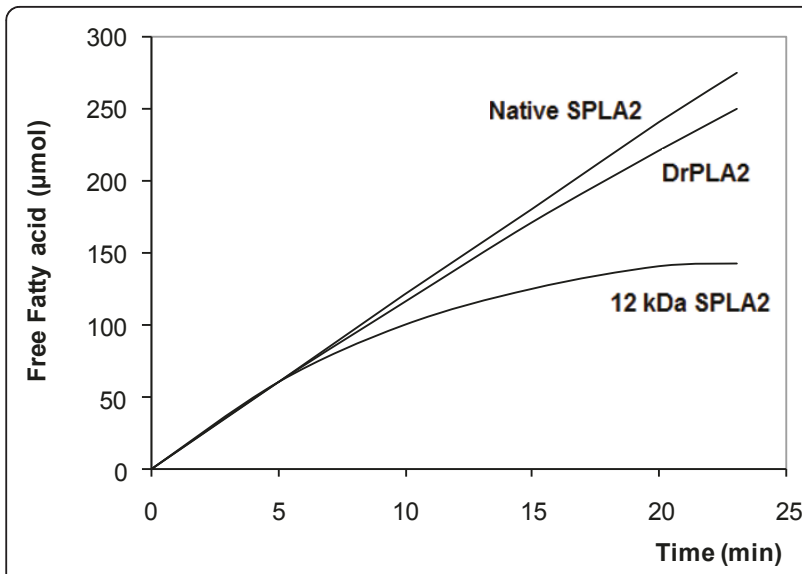

Figure 5 Kinetics of hydrolysis of PC emulsion by native SPLA2 (12 U), $12 \mathrm{kDa}$ SPLA2 (12 U) or by DrPLA2 (12 U). PLA2 activity was followed at $\mathrm{pH} 8.5$ and $40^{\circ} \mathrm{C}$ in the presence of $4 \mathrm{mM} \mathrm{NaTDC}$ and $8 \mathrm{mM} \mathrm{CaCl}$. Each data point represents an average of at least two independent experiments, each in duplicate.

functioned well at the anionic interface, but its activity decreased substantially at the zwitterionic interface possibly due to the uncoupling between calcium binding and substrate (inhibitor) binding [34].

\section{Conclusion}

Marine and mammal pancreatic PLA2 share a high amino-acid sequence homology. However; the absence of cross-immunoreactivity between DrPLA2, taken as mammal model, and anti-SPLA2 serum strengthens the idea that SPLA2 could be structurally different from mammalian pancreatic PLA2. Further investigations are needed to better establish the structure-function relationship of this class of enzyme and to identify key residues involved in substrate recognition responsible for biochemical differences between the classes of PLA2.

\section{Acknowledgements}

The authors extend their appreciation to the Deanship of Scientific Research at King Saud University for funding the work through the research group project No: RGP-VPP-070

\section{Author details}

'Biochemistry Department, Science College, King Saud University, P.O box 22452, Zip code 11495, Riyadh, Saudi Arabia. ${ }^{2}$ Laboratoire des biotechnologies végétales appliquées à l'amélioration des cultures, Faculty of Science of Sfax, Sfax University, 3038 Sfax, Tunisia.

\section{Authors' contributions}

ABB: designed the study and drafted the manuscript.

HM: helped to draft the manuscript and participated in the design of the study.

All authors read and approved the final manuscript.

\section{Competing interests}

The authors declare that they have no competing interests.

Received: 18 May 2011 Accepted: 26 July 2011 Published: 26 July 2011
References

1. Kudo I, Murakami M: Phospholipase A2 enzymes. Prostaglandins Other Lipid Mediat 2002, 68-69:3-58

2. Burke JE, Dennis EA: Phospholipase A2 structure/function, mechanism, and signaling. J Lipid Research 2009, 50:S237-S242.

3. Six DA, Dennis EA: The expanding superfamily of phospholipase A2 enzymes: classification and characterization. Biochim Biophys Acta 2000, 1488:1-19.

4. Rouault M, Bollinger JG, Lazdunski M, Gelb MH, Lambeau G: Novel mammalian group XII secreted phospholipase A2 lacking enzymatic activity. Biochemistry 2003, 42:11494-11503.

5. de Haas GH, Postema NM, Nieuwenhuizen W, van Deenen LLM: Purification and properties of an anionic zymogen of phospholipase A2 from porcine pancreas. Biochim Biophys Acta 1968, 159:118-129.

6. Stoll U: The analysis of phospholipids from cardiac membranes by phospholipase A. Fett/Lipid 1996, 98:26-30.

7. Yoshinori M: Structural and Functional Changes of Hen's Egg Yolk LowDensity Lipoproteins with Phospholipase A2. J Agric Food Chem 1997, 45:4558-4563.

8. Aoi N: Soy lysolecithin. Yukagaku J 1990, 39:10-15

9. Rana RL, Sarath G, Stanley DW: digestive phospholipase A2 in midguts of tobacco hornworms, Manduca sexta L. J Insect Physiol 1998, 44:297-303.

10. Audley MA, Shetty KJ, Kinsella JE: Isolation and properties of phospholipase A from pollock muscle. J Food Sci 1978, 43:771-1775.

11. Neas NP, Hazel JR: Partial purification and kinetic characterization of the microsomal phospholipase $A 2$ from thermally acclimated rainbow trout (Salmo gairdneri). J Comp Physiol B 1985, 155:461-469.

12. Aaen $B$, Jessen $F$, Jensen $B$ : Partial purification and characterization of a cellular acidic phospholipase A2 from cod (Gadus morhua). Comp Biochem Physiol B 1995, 110:547-554.

13. Zambonino Infante $\mathrm{L}$, Cahu CL: High dietary lipid levels enhance digestive tract maturation and improve Dicentrarchus labrax larval development. J Nutr 1999, 129:1195-1200.

14. Cherif S, Ben Bacha A, Ben Ali Y, Horchani H, Rekik W, Gargouri Y: Crab digestive phospholipase: a new invertebrate member. Bioresour Technol 2010, 101:366-71.

15. Pattus F, Slotboom AJ, de Haas GH: Regulation of Phospholipase A2 Activity by the Lipid-Water Interface: a Monolayer Approach. Biochemistry 1979, 18:2703-2707.

16. Zarai Z, Ben Bacha A, Horchani H, Bezzine S, Gargouri Y, Mejdoub H: A novel marine hepatopancreatic phospholipase $A 2$ with digestive and toxic activities. Archives of Biochemistry and Biophysics 2010, 494:121-129.

17. Bacha A, Karray A, Bouchaala E, Gargouri Y, Ben Ali Y: Purification and biochemical characterization of pancreatic phospholipase A2 from the common stingray Dasyatis pastinaca. Lipids in Health and Disease 2011, 10:32

18. Ben Bacha A, Gargouri Y, Bezzine S, Mejdoub H: Purification and biochemical characterization of phospholipase A2 from dromedary pancreas. Biochim Biophys Acta 2006, 1760:1202.

19. Bradford MM: A rapid and sensitive method for the quantification of microgram quantities of proteins utilizing the principle of protein-dye binding. Anal Biochem 1976, 72:248-254.

20. Abousalham A, Verger R: Egg yolk lipoproteins as substrates for lipases. Biochim Biophys Acta 2000, 1485:56-62.

21. Laemmli UK: Cleavage of structural protein during the assembly of the head of bacteriophage T4. Nature 1970, 227:680-685.

22. Bergman $H$, Jörnvall $T$ : Electroblotting of individual polypeptides from SDS/polyacrylamide gels for direct sequence analysis. Eur J Biochem 1987, 169:912.

23. Hewick RM, Hunkapiller MW, Hood LE: A gaz-liquid solid phase peptide and protein sequenator. J Biol Chem 1981, 256:7990-7997.

24. ISMEN A: Age, Growth, Reproduction and Food of Common Stingray (Dasyatis pastinaca L., 1758) in Iskenderun Bay, the Eastern Mediterranean. Fisheries Research 2003, 60:169-176.

25. Scott DL, Otwinowski Z, Gelb MH, Sigler PB: Crystal Structure of BeeVenom Phospholipase A2 in a Complex with a Transition-State Analogue. Science 1990, 250:1563-1566.

26. Yu BZ, Berg OG, Jain MK: The divalent cation is obligatory for the binding of ligands to the catalytic site of secreted phospholipase A2. Biochemistry 1993, 32:6485-6492. 
27. Mezna M, Ahmad T, Chettibi S, Drainas D, Lawrence AJ: Zinc and barium inhibit the phospholipase A2 from Naja naja atra by different mechanisms. Biochem J 1994, 301:503-508.

28. Qin S, Pande AH, Nemec KN, Tatulian SA: The N-terminal a-helix of pancreatic phospholipase $\mathrm{A} 2$ determines productive-mode orientation of the enzyme at the membrane surface. J Mol Biol 2004, 344:71-89.

29. Qin S, Pande AH, Nemec KN, He X, Tatulian SA: Evidence for the regulatory role of the $\mathrm{N}$-terminal helix of secretory phospholipase $\mathrm{A}(2)$ from studies on native and chimeric proteins. J Biol Chem 2005, 280:36773-36783.

30. Evenberg A, Meyer H, Verheij HM, DeHaas GH: Isolation and properties of prophospholipase A2 from horse pancreas and horse pancreatic juice. Biochim Biophys Acta 1977, 491:265-274.

31. Nieuwenhuizen W, Steenbergh P, De Haas GH: The isolation and properties of two prephospholipases A2 from porcine pancreas. Eur $J$ Biochem 1973, 40:1-7.

32. De Haas GH, Bonsen PP, Pieterson WA, Van Deenen LLM: Studies on phospholipase A2 and its zymogen from porcine pancreas action of the enzyme on short-chain lecithins. Biochim Biophys Acta 1971, 239:252-266.

33. Karray A, Frikha F, Ben Bacha A, Ben Ali Y, Gargouri Y, Bezzine S:

Biochemical and molecular characterization of purified chicken pancreatic phospholipase A2. FEBS J 2009, 276:4545-4554.

34. Huang B, Yu BZ, Rogers J, Byeon IJ, Sekar K, Chen X, Sundaralingam M, Tsai MD, Jain MK: Phospholipase A2 Engineering. Deletion of the CTerminus Segment Changes Substrate Specificity and Uncouples Calcium and Substrate Binding at the Zwitterionic Interface. Biochemistry 1996, 35:12164-12174.

doi:10.1186/1476-511X-10-124

Cite this article as: Ben Bacha and Mejdoub: Proteolytic cleavage of stingray phospholipase A2: Isolation and biochemical characterization of an active N-terminal form. Lipids in Health and Disease 2011 10:124.

\section{Submit your next manuscript to BioMed Central and take full advantage of:}

- Convenient online submission

- Thorough peer review

- No space constraints or color figure charges

- Immediate publication on acceptance

- Inclusion in PubMed, CAS, Scopus and Google Scholar

- Research which is freely available for redistribution

Submit your manuscript at www.biomedcentral.com/submit 